ISSN : $1979-7362$

\title{
Pendugaan Produktivitas Padi Sawah Berdasarkan Reflektansi (Indeks Vegetasi), Warna dan Kerapatan Tanaman

\author{
Nugrah Pratiwi ${ }^{1}$, Daniel ${ }^{1}$ dan Suhardi ${ }^{1}$
}

Program Studi Teknik Pertanian, Universitas Hasanuddin Makassar

\begin{abstract}
ABSTRAK
Jumlah produksi padi sawah dari tahun ke tahun mengalami perubahan yang disebabkan oleh beberapa faktor. Salah satu upaya dalam meningkatkan produktivitas padi sawah yaitu dengan mengatur kerapatan tanaman. Data produktivitas tanaman padi dapat diperoleh melalui pengukuran di lapangan dengan penggunaan teknologi yang salah satunya yaitu dengan memanfaatkan reflektansi tanaman. Berdasarkan data tersebut maka diperoleh hubungan antara reflektansi (indeks vegetasi), warna, kerapatan tanaman, dan produktivitas padi sawah untuk menduga produksi pada suatu kawasan yang sama. Pengukuran lapangan berupa pengukuran reflektansi menggunakan spektrometer, pengambilan potret kenampakan lahan, pengukuran tinggi tanaman, biomassa, dan produktivitas padi sawah. Hasil yang diperoleh menunjukkan pada awal pertumbuhan hingga 38 HST, reflektansi warna lahan dengan tanaman padi berada pada kuadran IV yaitu antara merah dan biru. Hal ini disebabkan warna kenampakan air dan tanah masih mendominasi. Kemudian akan berubah pada puncak pertumbuhan hingga memasuki masa panen menuju kuadran II yaitu antara hijau dan kuning dimana tanaman padi mendominasi. Estimasi produktivitas tanaman padi yang diperoleh memiliki hubungan yang akurat dengan hasil pengukuran. Kerapatan tanaman memiliki hubungan yang cukup kuat dengan peningkatan produktivitas padi (ton/ha), koefisien determinasi (R2) yaitu 0,7. Tanaman padi pola tanam Legowo 2-1 lebih memiliki pengaruh terhadap peningkatan indeks dibandingkan pola tanam Tegel. Nilai indeks vegetasi tanaman padi memiliki hubungan yang lemah dengan produktivitas padi (ton/ha) pada beberapa indeks kecuali RDVI.
\end{abstract}

Kata kunci: spektrometer, indeks vegetasi, kerapatan tanaman, warna, produktivitas padi.

\section{PENDAHULUAN}

\section{Latar Belakang}

Ketahanan pangan suatu negara
dapat diketahui berdasarkan jumlah
produksi makanan pokok di negara tersebut
per tahun.

Di Indonesia, jumlah produksi padi merupakan indikator ketahanan pangan dimana beras menjadi makanan pokok mayoritas penduduk. Produksi padi pada tahun 2015 diperkirakan sebesar 75,55 juta ton gabah kering giling (GKG) atau mengalami kenaikan 4,70 juta ton yakni $6,64 \%$ dibandingkan produksi padi pada tahun 2014 (BPS, 2016).

Pendugaan jumlah produksi padi sangat penting untuk mengevaluasi kecukupan persediaan pangan. Data jumlah produksi yang dihasilkan kemudian dijadikan bahan pertimbangan dalam mengambil kebijakan terhadap tercukupinya kebutuhan pangan suatu negara atau wilayah. Produksi padi sawah dari tahun

ke tahun mengalami perubahan yang disebabkan oleh beberapa faktor seperti jenis tanah, jenis pupuk, hama dan penyakit tanaman serta perubahan iklim. Selain itu juga dipengaruhi oleh jenis varietas maupun pola tanam padi sawah tersebut. Dalam teknologi budidaya, kerapatan tanaman merupakan salah satu komponen dalam manipulasi tanaman untuk meningkatkan hasil. Pada umumnya, pada kondisi jarak tanam yang sempit tanaman padi akan mengalami penurunan kualitas pertumbuhan dibandingkan pada kondisi jarak tanam yang lebar (Abdulrachman, 2013).

Data produktivitas tanaman padi dapat diperoleh melalui pengukuran di lapangan dan penggunaan teknologi yang salah 
satunya yaitu dengan memanfaatkan reflektansi warna untuk memperkirakan jumlah produksi padi pada sawah yang memiliki ciri yang sejenis.

\section{Tujuan dan Manfaat}

Tujuan dilakukannya penelitian ini adalah mengetahui hubungan antara reflektansi (indeks vegetasi), warna, kerapatan tanaman dan produktivitas padi sawah untuk menduga produksi pada suatu kawasan yang sama.

Manfaat penelitian ini adalah sebagai informasi dalam prediksi produksi padi sawah.

\section{METODOLOGI PENELITIAN}

\section{Waktu dan Tempat}

Penelitian pendugaan produktivitas padi sawah berdasarkan reflektansi (indeks vegetasi), warna dan kerapatan tanaman telah dilaksanakan pada bulan Mei 2016 hingga Agustus 2016 di Desa Alatangngae, kecamatan Bantimurung, Kabupaten Maros.

\section{Alat dan Bahan}

Alat yang digunakan pada penelitian ini adalah mistar, laptop, kamera (16 MP), luxmeter, spektrometer StellarNet-GREENWave, software SpectraWiz, timbangan analitik (akurasi 0,1 g), dan software ER Mapper.

Bahan yang digunakan pada penelitian ini adalah alat tulis, rumpun padi pada setiap petakan, peta dasar lahan petakan sawah .

\section{Prosedur Kerja}

Melakukan survei penentuan lokasi penelitian.Memberikan penanda pada petakan sawah sebagai sampel sebanyak 9 petakan masing-masing $200 \mathrm{~cm}$ x $200 \mathrm{~cm}$.

Pengambilan data lapangan

1. Tinggi Tanaman

Pengukuran tinggi tanaman padi yang malainya belum keluar dilakukan dari permukaan tanah sampai ujung daun tertinggi sedangkan tinggi tanaman padi yang malainya sudah keluar dilakukan dari permukaan tanah hingga ujung malai tertinggi. Pengambilan data dilakukan setiap 2 minggu.

2. Ground Cover

Pengambilan data dilakukan dengan memotret sampel petakan sawah dengan ketinggian alat 1 meter dari kanopi dengan sumbu kamera tegak lurus terhadap permukaan bumi. Pengambilan data dilakukan setiap dua minggu. Persentase Ground Cover (GC) sampel petakan sawah dihitung menggunakan persamaan:

$\mathrm{GC}=($ Area tertutup tanaman $) /($ Area

keseluruhan) x 100\%

Dimana:

$\mathrm{GC}=$ Ground Cover $(\%)$.

3. Reflektansi tanaman

Sebelum pengambilan data dilakukan, terlebih dahulu diukur intensitas cahaya matahari menggunakan luxmeter. Pengambilan data reflektansi tanaman menggunakan alat spektrometer dengan ketinggian alat yaitu 1,5 meter dari kanopi dan sudut kemiringan $45^{\circ}$. Setiap pengambilan data dilakukan sebanyak minimal tiga kali pengulangan.

$\begin{array}{r}\text { Pengambilan data produktivitas } \\ \text { pengukuran }\end{array}$
padi dan rata
biomassaPengambilan
produktivitas padi dilakukan pada saat
panen berlangsung. Selain itu, juga
$\begin{aligned} & \text { dilakukan pengukuran biomassa } \\ & \text { tanaman. }\end{aligned}$

4. Analisis

Analisis Ground Cover (GC) Ground Cover menunjukkan perbandingan area tertutup tanaman padi dengan area keseluruhan penanaman. Kenampakan Ground Cover dinyatakan dalam persen. 
Analisis

warnaAnalisis reflektansi warna meliputi perubahan-perubahan niai L*a*b.

Analisis data dengan indeks vegetasiSimpel Ratio (SR)

Normalized Difference Vegetation Index (NDVI)

Soil Adjusted Vegetation Index (SAVI)

Modified Soil Adjusted Vegetation Index (MSAVI)

Infrared Percentage Vegetation Index (IPVI)

Renormalized Difference Vegetation Index (RDVI)

5. Diagram Alir Penelitian

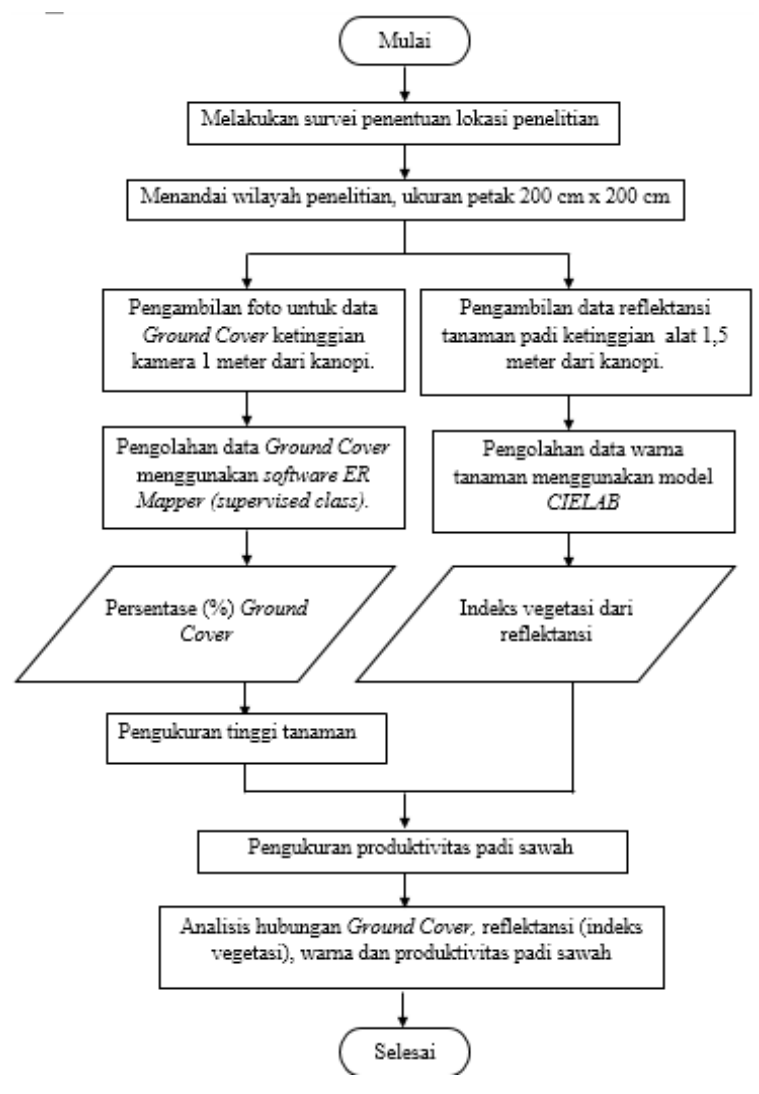

\section{HASIL DAN PEMBAHASAN}

\section{Tinggi Tanaman}

Pertumbuhan tanaman dapat diketahui berdasarkan perubahan tinggi tanaman terhadap umur tanaman seperti pada gambar berikut.

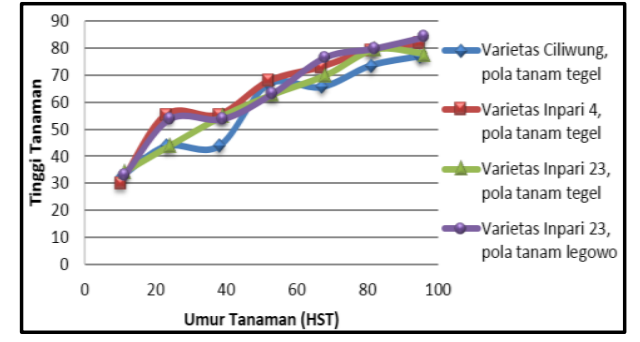

Gambar 1. Tinggi tanaman padi

Pertambahan tinggi tanaman akan meningkat sesuai dengan umur tanaman terutama pada 10 hingga 53 HST yang merupakan masa vegetatif tanaman padi. Akan tetapi grafik tinggi tanaman padi tidak jauh berbeda pada 23 dan 38 HST pada setiap varietas. Hal ini disebabkan pada umur tersebut, daun tanaman padi yang lebih panjang akan mudah terkulai sehingga pengukuran tinggi tanaman dilakukan dari permukaan tanah hingga ujung daun tertinggi.

Tinggi tanaman padi varietas Ciliwung pola tanam Tegel (dapat dilihat pada Gambar 1), mengalami penurunan pada umur 68 HST yakni tanaman padi berada pada fase berbunga dimana malai telah keluar sehingga pengukuran tinggi tanaman dilakukan dari permukaan tanah hingga ujung malai tertinggi. Pada umur 96 HST pertambahan tinggi tanaman padi menjadi lambat. Hal ini disebabkan karena tanaman padi memasuki fase reproduktif hingga pematangan yaitupertumbuhan jumlah anakan dan daun telah mencapai maksimal.

\section{Ground Cover}

Ground Cover menunjukkan persentase area yang tertutup tanaman terhadap keseluruhan area tempat penanaman. Persentase Ground Cover yang diperoleh sebagai berikut.

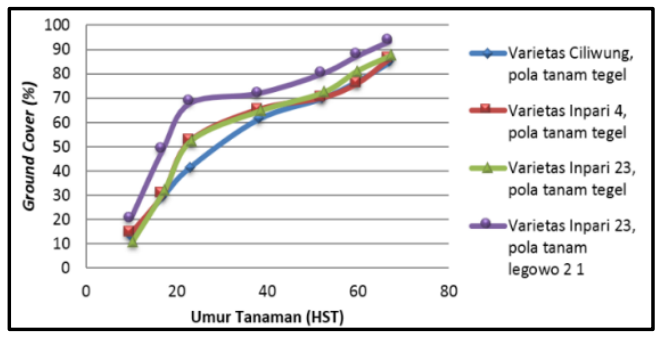

Gambar 2. Persentase Ground Cover 
Berdasarkan Gambar 2 menunjukkan peningkatan persentase Ground Cover sesuai dengan umur tanaman. Persentase Ground Cover akan terus meningkat terutama ketika tanaman padi memasuki fase vegetatif yang ditandai dengan pertumbuhan batang, daun dan peningkatan jumlah anakan. Tanaman padi varietas berbeda yakni Ciliwung, Inpari 4 dan Inpari 23 yang ditanam dengan pola tanam Tegel memiliki persentase Ground Cover masing-masing 85\%, 86\% dan $87 \%$ pada umur 67 HST. Tanaman padi varietas Inpari 23 dengan pola tanam berbeda yakni Legowo 2-1 dan Tegel, diperoleh persentase Ground Cover pola tanam Legowo 2-1 lebih tinggi yaitu $93 \%$ dibandingkan pola tanam Tegel.

\section{Reflektansi Tanaman}

Pada awal pertumbuhan tanaman padi, nilai reflektansi cenderung tinggi pada cahaya tampak kanal blue (455-492 $\mathrm{nm}$ ) dan red (622-780 nm) (dapat dilihat pada Gambar 3). Hal ini disebabkan karena pada fase tersebut tanaman masih muda dan kecil sehingga penyerapan pada kanal blue dan red untuk proses fotosintesis masih rendah. Selain itu, lahan tempat tumbuh tanaman masih didominasi oleh tanah dan air.

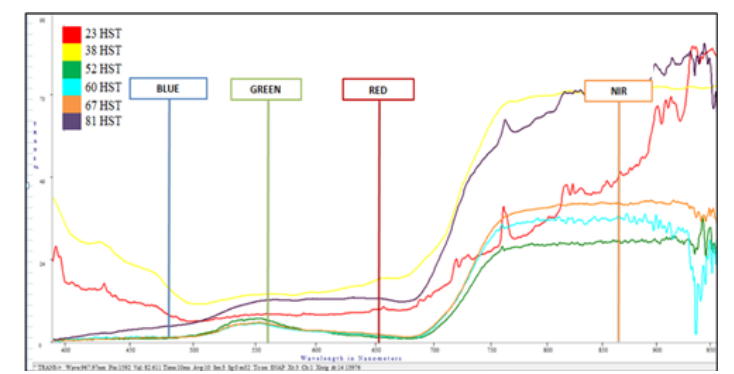

Gambar 3. Reflektansi tanaman padi

Nilai reflektansi tanaman padi pada kanal green dan NIR cenderung tinggi pada umur 52, 60 dan 67 HST yang menunjukkan dominasi tanaman pada lahan tempat penanaman (dapat dilihat pada Gambar 4). Hal tersebut diketahui berdasarkan pemantulan cahaya pada kanal green dan NIR serta penyerapan cahaya pada kanal red dan blue oleh klorofil.
Pada umur 82 HST, nilai reflektansi meningkat pada kanal red (622-780 nm) yakni pada fase reproduktif tanaman terutama pembungaan dan fase pematangan hingga masa panen.

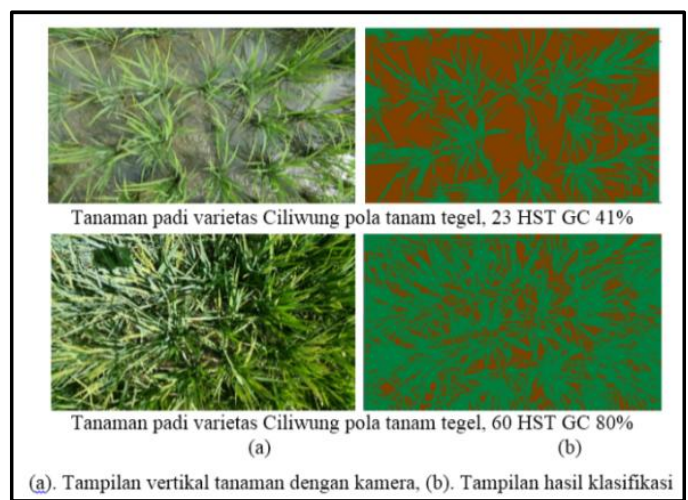

Gambar 4. Kenampakan tanaman padi pada 23 dan 60 HST.

Perubahan warna tanaman terjadi pada awal pertumbuhan hingga memasuki masa panen. Nilai L menunjukkan terang gelap daun tanaman padi berdasarkan HST tanaman. Nilai L yang diperoleh yaitu tinggi pada awal pertumbuhan dan mengalami penurunan kecerahan warna pada 52 hingga 67 HST. Hal ini disebabkan karena tanaman berwarna hijau gelap dengan vegetasi yang padat. Akan tetapi, pada umur 81 HST nilai kecerahan tanaman yang diperoleh meningkat dibandingkan nilai $\mathrm{L}$ sebelumnya. Hal ini disebabkan warna tanaman padi mulai menguning.

Pada awal pertumbuhan hingga umur 38 HST, reflektansi warna tanaman padi berada pada kuadran IV yaitu antara merah dan biru (magenta). Warna tersebut merupakan perpaduan antara $a^{*}$ positif dengan $b^{*}$ negatif. Hal ini disebabkan karena daun tanaman padi masih muda dan kecil sehingga warna kenampakan lahan penanaman masih mendominasi. Kemudian reflektansi warna tanaman akan berubah pada puncak pertumbuhan hingga memasuki masa panen menuju kuadran II yaitu antara hijau dan kuning. Tanaman padi memiliki warna diantara nilai $a^{*}$ negatif dan $b^{*}$ positif (dapat dilihat pada Gambar 5). 


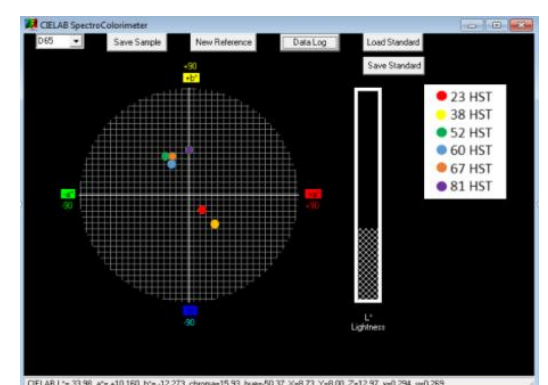

Gambar 5. Perubahan nilai L*a*b* tanaman padi.

\section{Indeks Vegetasi}

Pada awal penanaman hingga tanaman padi berusia 4 minggu setelah tanam (MST), sawah masih didominasi oleh kenampakan air dan tanah sehingga diperoleh nilai indeks vegetasi yang rendah. Seiring dengan pertumbuhan tanaman, nilai indeks vegetasi yang diperoleh akan semakin tinggi disebabkan tingginya kandungan klorofil tanaman serta mencapai puncaknya pada masa fase awal generatif. Nilai indeks vegetasi akan menurun pada fase pengisian bulir dan seterusnya sampai masa panen.
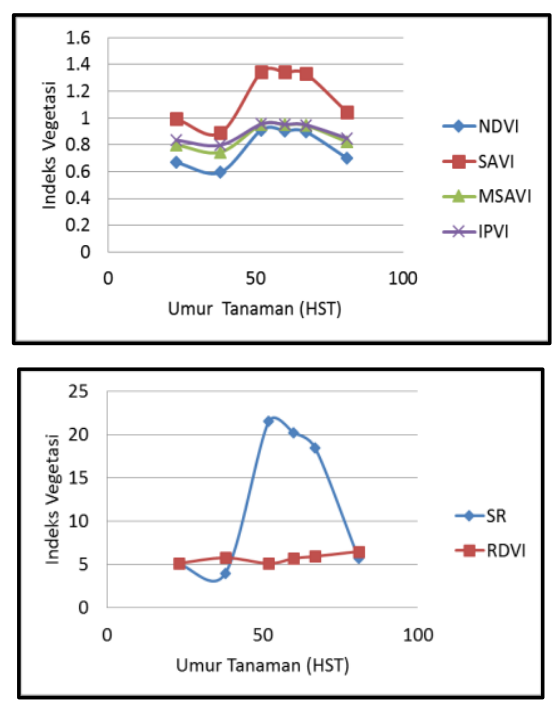

Gambar 7. Indeks vegetasi tanaman padi varietas Ciliwung pola tanam Tegel.

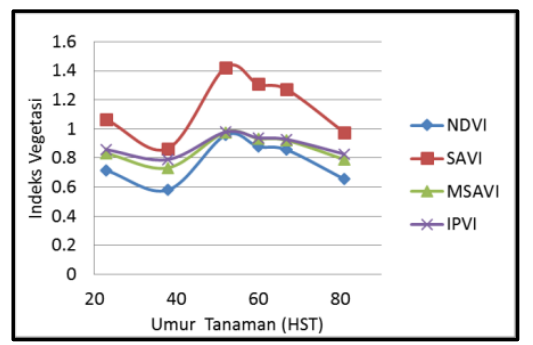

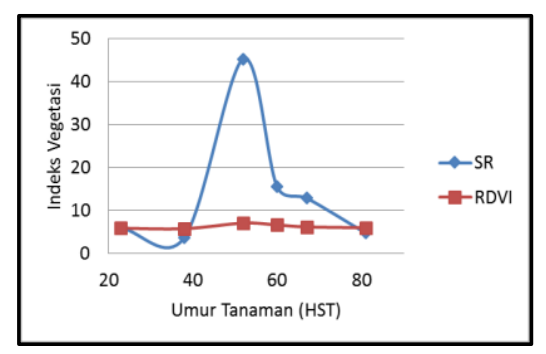

Gambar 8. Indeks vegetasi tanaman padi varietas Inpari 4 pola tanam Tegel.
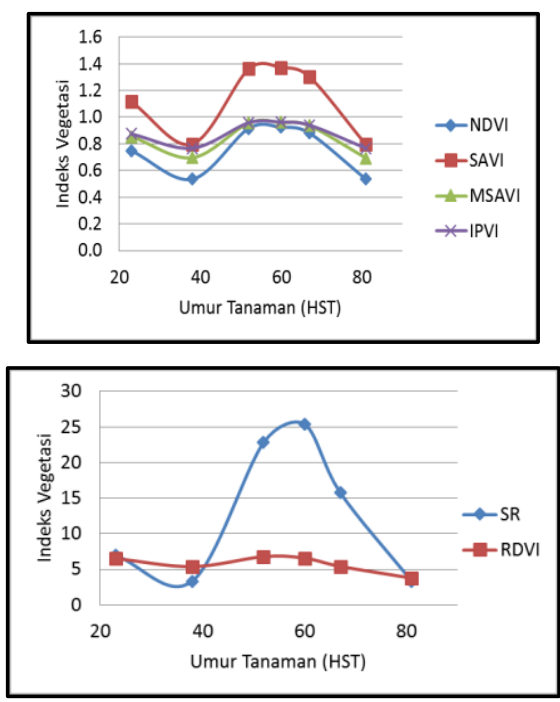

Gambar 9. Indeks vegetasi tanaman padi varietas Inpari 23 pola tanam Tegel
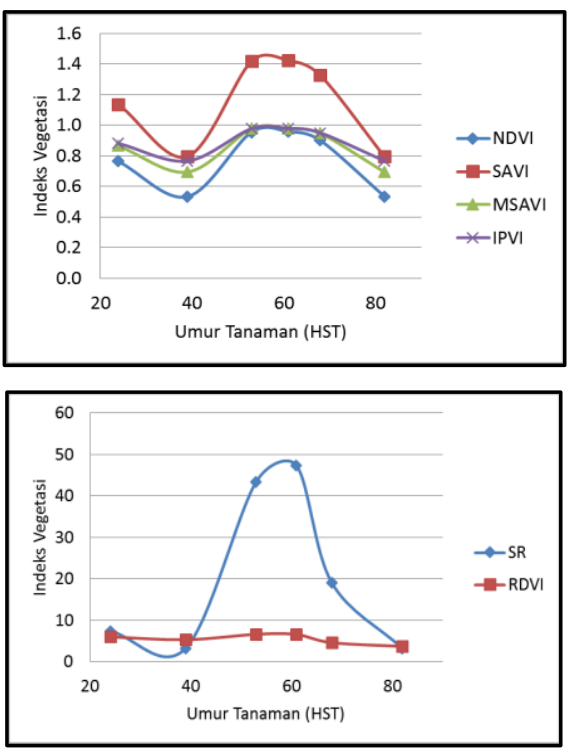

Gambar 10. Indeks vegetasi tanaman padi varietas Inpari 23 pola tanam Legowo 2-1.

Pada umur 23 HST diperoleh nilai indeks vegetasi dimana lahan penanaman masih didominasi oleh air dan tanah menyebabkan nilai reflektansi yang tinggi pada kanal blue, red, green dan NIR 
sehingga nilai indeks vegetasi akan tinggi. Pada umur 38 HST terjadi penyerapan pada kanal blue, red dan NIR menyebabkan penurunan nilai indeks vegetasi dimana tanaman padi mulai mendominasi lahan penanaman dengan kenampakan tanah. Nilai indeks vegetasi akan meningkat terutama fase vegetatif tanaman hingga pada fase awal generatif dimana tanaman aktif melakukan fotosintesis. Berkurangnya kandungan klorofil tanaman yang terjadi terutama pada fase pematangan hingga masa panen menyebabkan penurunan nilai indeks vegetasi pada HST tersebut. Hal ini sesuai dengan Sudiana (2008) bahwa tingkat kesuburan tanaman dipengaruhi oleh kandungan klorofil.

\section{Biomassa}

Biomassa merupakan integrasi antara dan hampir semua peristiwa yang dialami tanaman. Biomassa berikut merupakan biomassa basah yang mana masih pada setiap bagian tanaman memiliki kandungan air.

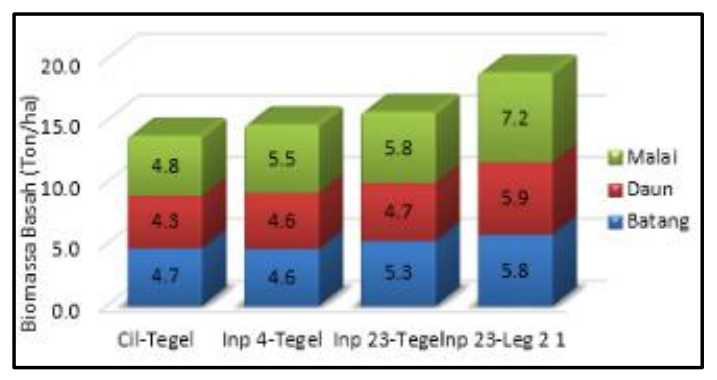

Gambar 11. Biomassa basah tanaman padi (ton/ha)

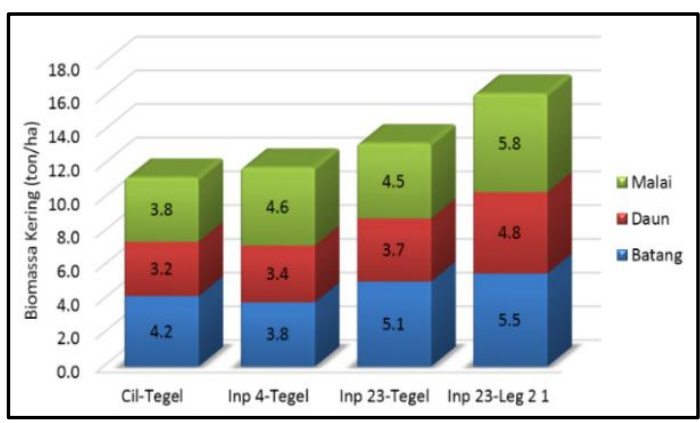

Gambar 12. Biomassa kering tanaman padi (ton/ha).

Berdasarkan Gambar 11 dan 12, biomassa yang dihasilkan tanaman padi varietas Inpari 23 lebih tinggi dibandingkan varietas Inpari 4 dan Ciliwung. Hal ini sesuai dengan BPPP (2016) bahwa dari ketiga varietas tersebut tanaman padi Inpari 23 memiliki rata-rata hasil yang paling tinggi yaitu 6,9 ton/ha GKG dengan potensi hasil sebesar 9,2 ton/ha.

Tanaman padi inpari 23 yang ditanam dengan pola tanam Legowo 2-1 lebih tinggi biomassanya dibandingkan dengan pola tanam Tegel. Hal ini sesuai dengan Abdulrachman (2013), bahwa tanaman dengan sistem tanam Legowo dapat meningkatkan produktivitas tanaman padi dibandingkan dengan sistem tanam Tegel.

\section{Hubungan Estimasi Produktivitas Padi dengan Pengukuran Gabah Hasil Panen}

Produktivitas padi berdasarkan estimasi dan pengukuran gabah hasil panen memiliki hubungan cukup kuat. Hal ini diketahui berdasarkan titik-titik yang menggambarkan hubungan tersebut mendekati garis linear. Namun, terdapat beberapa data yang overestimated yaitu memiliki biomassa malai yang tinggi tetapi memiliki hasil panen yang rendah (dapat dilihat pada Gambar 13).

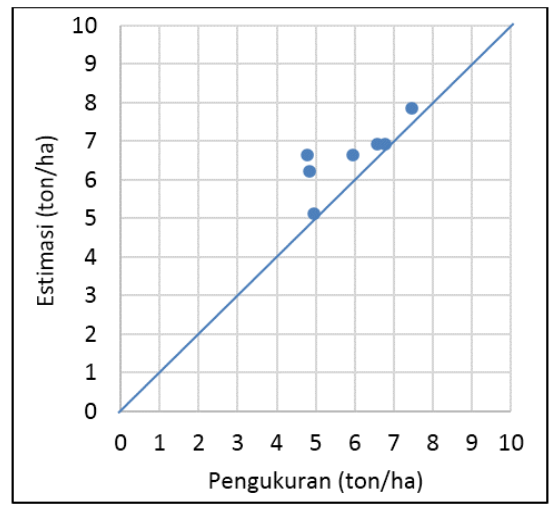

Gambar 13. Hubungan antara estimasi produktivitas padi dengan pengukuran gabah hasil panen.

Fase reproduktif tanaman terutama pengisian bulir padi memiliki hubungan dengan tingginya hasil panen dimana ketersedian cahaya matahari turut berpengaruh. Hal ini sesuai dengan Useng (2014) bahwa salah satu kondisi yang 
menyebabkan tanaman padi yang memiliki biomassa yang tinggi namun hasil panennya rendah yaitu tanaman tidak menerima cahaya matahari yang cukup selama masa fase reproduktif, meskipun memiliki nilai NDVI yang tinggi.

\section{Hubungan Ground Cover dengan Indeks Vegetasi Persentase}

Ground Cover akan meningkat seiring dengan pertumbuhan tanaman. Peningkatan Ground Cover akan sangat terlihat ketika tanaman memasuki masa vegetatif. Reflektansi tanaman berpengaruh terhadap indeks vegetasi yang diperoleh.

Berdasarkan hasil pengukuran reflektansi, diperoleh indeks vegetasi pada pola tanam Tegel yaitu sebagai berikut.
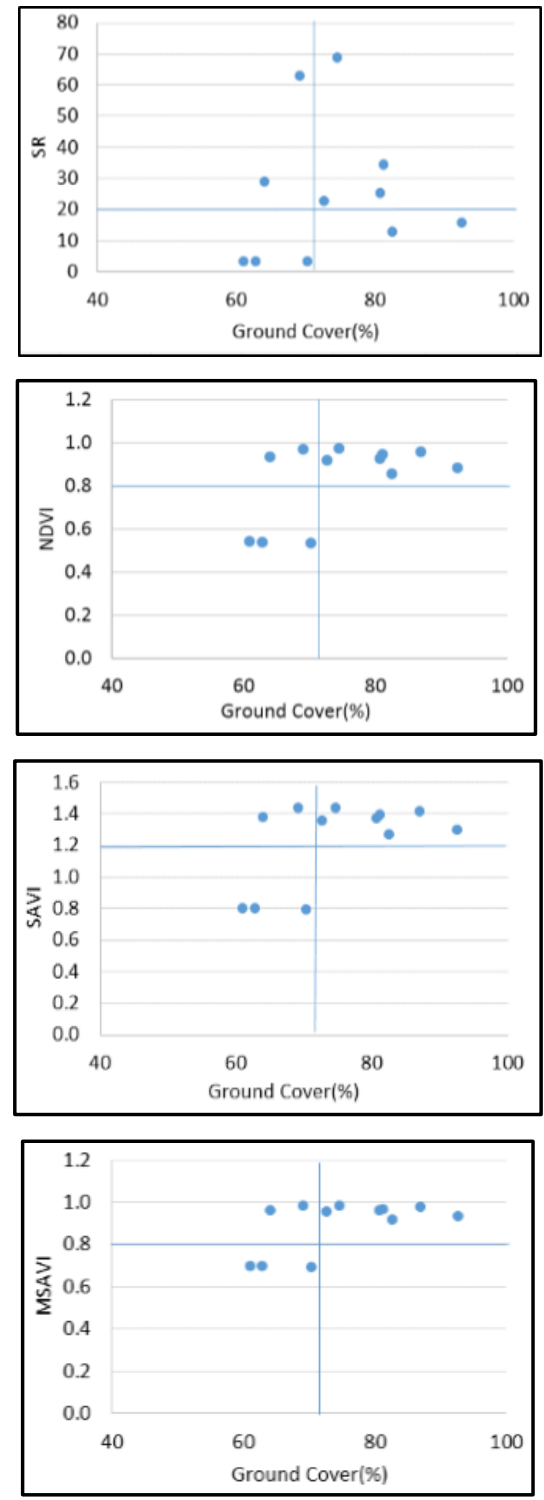
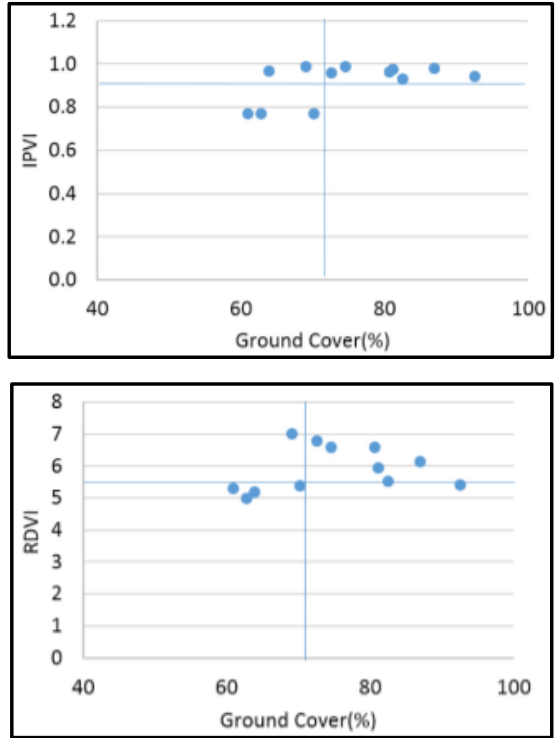

Gambar 14. Hubungan Ground Cover (\%) dengan indeks vegetasi pada pola tanam

Tegel

Berdasarkan hasil pengukuran reflektansi, diperoleh indeks vegetasi pada pola tanam Legowo 2-1 yaitu sebagai berikut.
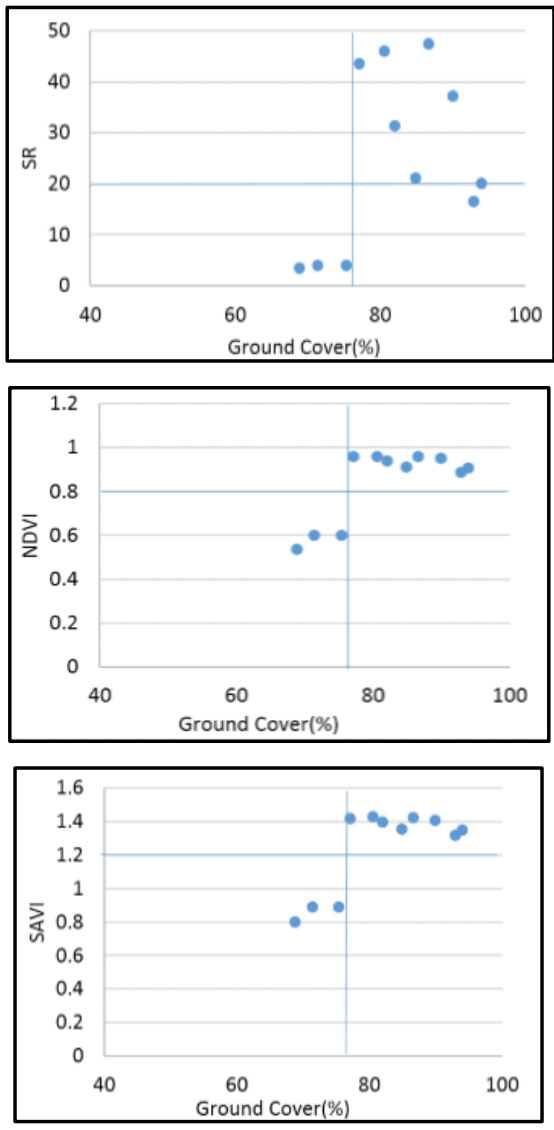

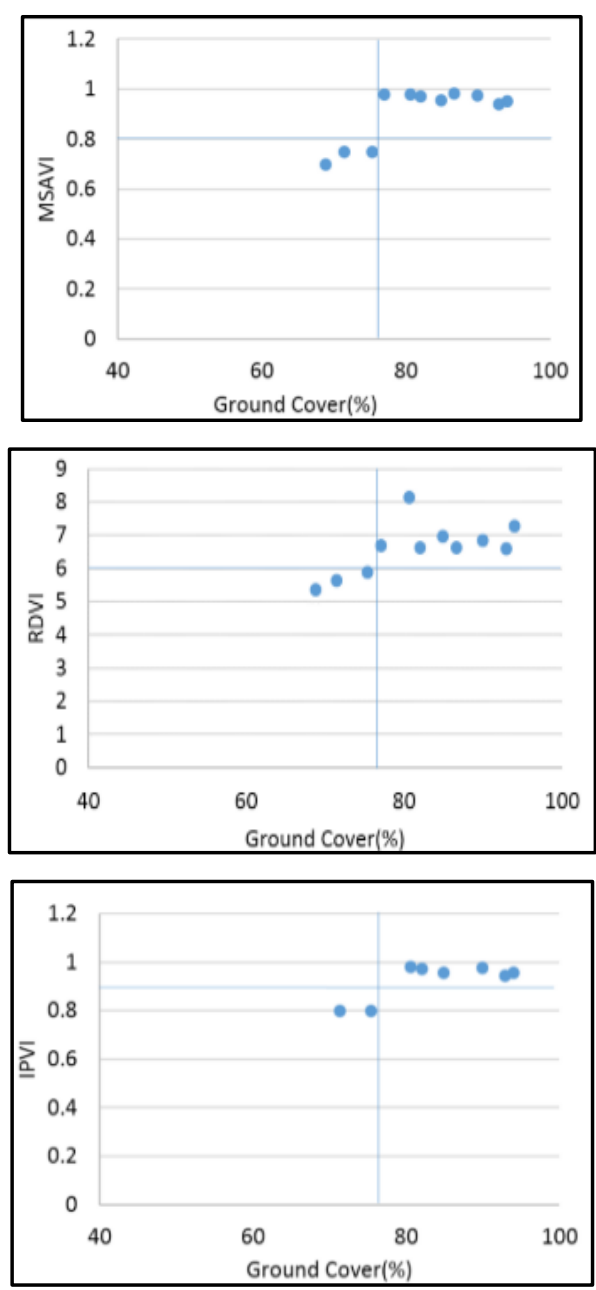

Gambar 15. Hubungan Ground Cover (\%) dengan indeks vegetasi pada pola tanam Legowo 2-1

Pada Gambar 13 dan 14 menunjukkan hubungan antara Ground Cover dengan indeks vegetasi tanaman padi varietas inpari 23. Pola tanam Tegel dan pola tanam Legowo 2-1 digunakan sebagai perbandingan. Pola tanam Legowo 2-1 memiliki pengaruh terhadap peningkatan indeks vegetasi dibandingkan dengan pola tanam Tegel. Tanaman padi pola tanam Legowo 2-1 memiliki nilai indeks vegetasi yang cenderung tinggi dengan adanya peningkatan Ground Cover. Sedangkan pada tanaman padi pola tanam Tegel memiliki nilai indeks vegetasi yang tidak menentu yakni adanya nilai indeks vegetasi yang tinggi pada Ground Cover yang rendah. Kerapatan tanaman tidak memiliki pengaruh yang signifikan terhadap peningkatan nilai indeks vegetasi. Hal tersebut disebabkan terdapat faktor-faktor yang mempengaruhi reflektansi tanaman diantaranya yaitu kenampakan lahan penanaman serta banyaknya cahaya yang diserap dan dipantulkan oleh objek.

\section{Hubungan Ground Cover dengan Produktivitas Padi}

Ground Cover menggambarkan persentase tutupan vegetasi pada lahan penanaman. Semakin tinggi persentase Ground Cover yang diperoleh maka semakin subur tanaman tersebut. Hal ini berkaitan dengan produktivitas tanaman padi yang dihasilkan.

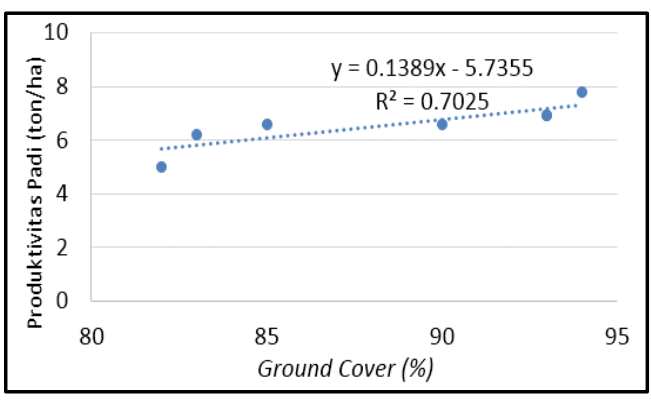

Gambar 16. Hubungan Ground Cover (\%GC) dengan produktivitas padi (ton/ha).

Ground Cover (\%GC) memiliki korelasi yang cukup kuat dengan produktivitas tanaman padi (ton/ha) (dapat dilihat pada Gambar 15). Hal ini diketahui dengan koefisien determinasi (R2) yang dihasilkan yaitu 0,70 . Artinya, banyaknya vegetasi pada suatu lahan turut mempengaruhi produktivitas tanaman (ton/ha). Hal ini sesuai dengan Shadrina (2015), bahwa produktivitas padi di daerah penelitian dapat diprediksi melalui nilai indeks vegetasi NDVI, nilai Indeks Luas Daun (ILD), dan Ground Cover (GC). Nilai Indeks Luas Daun, kontribusinya terhadap produktivitas padi sebesar $81.50 \%$ dan kontribusi Ground Cover sebesar 67,6\%.

\section{Hubungan Indeks Vegetasi dengan Produktivitas Padi}

Fase awal generatif yaitu saat tanaman padi memasuki awal pembungaanbunting (umur tanaman padi sekitar 10-11 minggu setelah tanam/MST merupakan fase pertumbuhan tanaman yang diduga mempunyai hubungan erat dengan produksi 
tanaman padi. Adanya peningkatan fotosintesis tanaman menyebabkan nilai indeks vegetasi pada fase tersebut meningkat.

Berikut adalah hubungan antara indeks vegetasi dengan produktivitas gabah (ton/ha) hasil panen dilapangan.
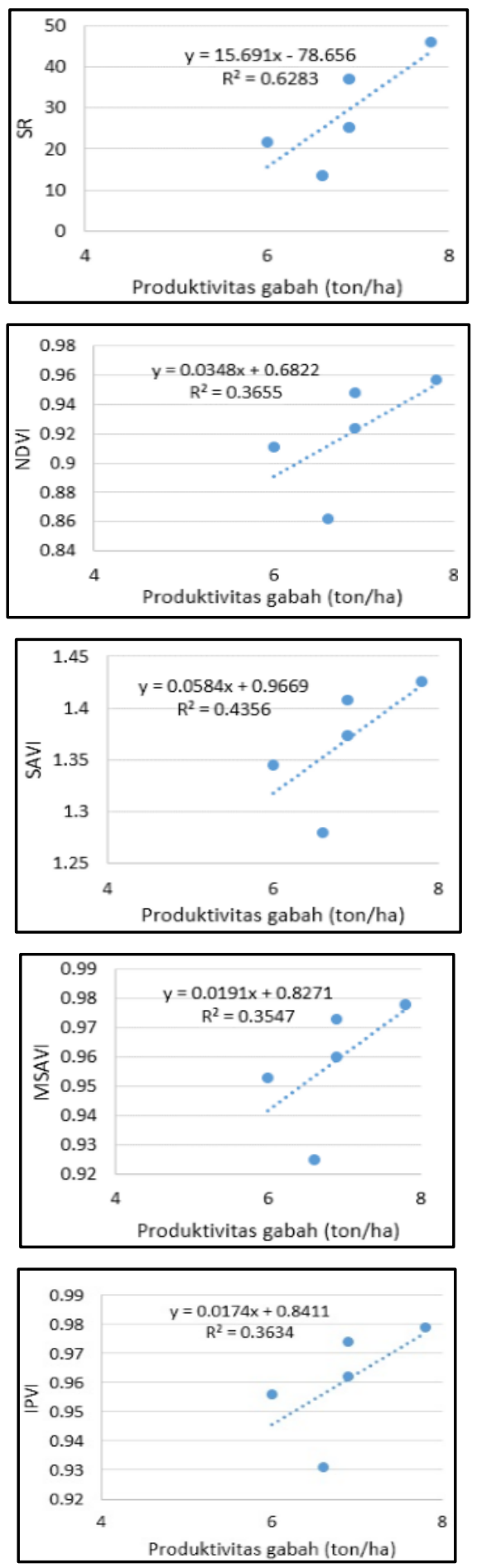

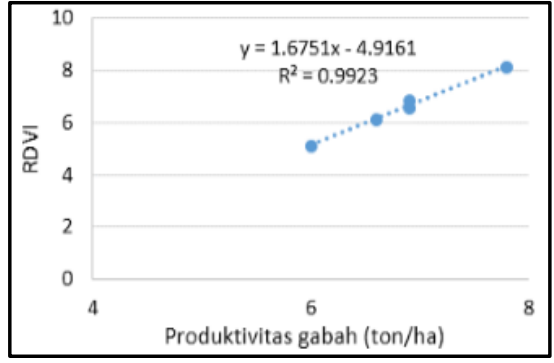

Gambar 16. Hubungan indeks vegetasi dengan produktivitas gabah (ton/ha)

Gambar 16 menunjukkan antara indeks vegetasi dengan produktivitas padi (ton/ha) memiliki hubungan yang lemah. Hal ini berdasarkan koefisien determinasi (R2) yang dihasilkan berada dibawah 0,5. Rendahnya nilai beberapa indeks vegetasi yang diperoleh disebabkan nilai reflektansinya.

Akan tetapi, korelasi yang tinggi diperoleh untuk RDVI yakni 0,9. Hal ini terjadi karena RDVI merupakan indeks yang tidak terpengaruh oleh geometri tanah dan cahaya sehingga nilai reflektansi yang diperoleh akan tetap stabil.

\section{KESIMPULAN}

\section{Kesimpulan}

Berdasarkan penelitian yang telah dilakukan, diperoleh kesimpulan sebagai berikut:

1. Pada awal pertumbuhan hingga $38 \mathrm{HST}$, reflektansi warna lahan dengan tanaman padi berada pada kuadran IV yaitu antara merah dan biru. Kemudian akan berubah pada puncak pertumbuhan hingga memasuki masa panen menuju kuadran II yaitu antara hijau dan kuning.

2. Produktivitas padi berdasarkan estimasi dan pengukuran gabah hasil panen memiliki hubungan yang cukup akurat.

3. Kerapatan tanaman memiliki hubungan yang cukup kuat dengan peningkatan produktivitas padi (ton/ha) dengan koefisien determinasi (R2) yaitu 0,7.

4. Tanaman padi pola tanam Legowo 2-1 lebih memiliki pengaruh terhadap 
peningkatan indeks dibandingkan pola tanam Tegel.

5. Nilai indeks vegetasi tanaman padi memiliki hubungan yang lemah dengan produktivitas padi (ton/ha) pada beberapa indeks kecuali RDVI.

\section{DAFTAR PUSTAKA}

Abdulrachman S, J. M. Made, A. Nurwulan, G.Indra., P. Sasmita dan A.

Guswara. 2013. Panduan Sistem

Tanam Legowo. Badan Penelitian dan Pengembangan Pertanian. Sukamandi.

BPPP (Badan Penelitian dan Pengembangan Pertanian). 2016. Deskripsi Varietas Unggul Padi. http://bbpadi.litbang. pertanian.go.id/index.php/en/publika si/buku/content/item/450-deskripsivarietas- 2016. Diakses pada Selasa, 7 Juni 2016.

BPS (Badan Pusat Statistik). 2016. Produksi Padi Tahun 2015. Http://www. bps. go.id/Brs/ view /id/1157. Diakses pada Selasa, 7 Juni 2016.

Shadrina, N. 2015. Pendugaan Produktivitas Tanaman Padi Sawah Berdasarkan Citra Digital dan Spektrometer. Tesis Universitas Hasanuddin. Makassar.

Sudiana, D dan D. Elfa. 2008. Analisis Indeks Vegetasi Menggunakan Data Satelit NOAA/AVHRR dan TERRA /AQUA-MODIS. Fakultas Teknik. Universitas Indonesia. Jakarta. 